\title{
A Critical Analysis of the US Role in the World
}

\author{
* Dr. Muhammad Tariq, Lecturer (Corresponding Author) \\ ** Amjad Ali Khan, Lecturer \\ *** Ejaz Khan, Visiting Lecturer
}

\begin{abstract}
The US has played a significant role in the world particularly during the post-world War-II period. The changing role has been ascribed by some to the Trump administration while by others it has been attributed to the Obama administration. Democratic Peace Theory provides the basic theoretical framework for the study while four key factors of the US role have been elucidated. The focus of this paper is to investigate the role played by the US in the post-World War-II era to date coupled with the changing behavior of the US from time to time during different regimes. The main objectives of the paper include global leadership, defense, and promotion of liberal international order, freedom, democracy, and prevention of the emergence of hegemonic power. It is an important fact that the US has played the role of world hegemony, particularly in the post-World War-II era.
\end{abstract}

Keywords: US, World Affairs, Changing Role

\section{Introduction}

The US has been playing a very significant role in the politics of the world since the World War-II. It has shown its presence in most of the countries of the world in many forms. This can be viewed as an establishing factor in the overall context for the policymakers of the US in developing, implementing, and measuring the success of the US policies and actions on particular issues of international nature, and for foreign countries and observers for the interpretation and understanding of the actions of the US on the stage of the world (Rourke \& Moodie, 2020).

Some observers are of the view that the US, after being stable for the last seventy years since the World War-II in 1945 is going to undergo a potentially historic change. The change viewed through the prism of security, freedom, and prosperity could have a profound effect on the future policies of the US. It could affect the US policies in some key areas such as relations with allies and other countries, defense plans and programs, trade and international finance, foreign assistance, and human rights.

The role of the US in the post-World War-II has undergone drastic changes and has never shown any stagnation in its dealing with the rest of the world in so far as its foreign policy or international relations is concerned. This role can be described in four key areas:

i) Global leadership

ii) Defense and promotion of the liberal international order

iii) Defense and promotion of freedom, democracy, and human rights; and

iv) Prevention of the emergence of regional hegemony in Eurasia

These key elements play the most significant role in determining the US role in the affairs of the world. Due to the enhanced role of the US, it is pertinent to mention these key elements in some detail to know about the role played by it. The most important phenomenon in this regard is the US presence in most parts of the world by showing its key role in determining the internal as well as the external affairs of the countries where it has been showing its presence.

\section{Global Leadership}

The traditional role played by the US in the affairs of the world since the culmination of the $2^{\text {nd }}$ World War, can be described of great significance in the identification of issues of international nature, action-taking for getting these issues redressed, while at the same time, paving the way for other states by following, organizing and implementing the standard set by it for the resolution of issues (Scheffer,

\footnotetext{
* Department of Political Science, Hazara University Mansehra Email: tariqawkum252@gmail.com

** Department of Political Science, Hazara University Mansehra

*** Department of Political Science, Hazara University Mansehra
} 
Kinane, Quencez, \& Wickett, 2016). This mainly focuses first to identify the key issues and then take concrete steps for the resolution of the issues and that too while taking into confidence the major stakeholders of the country. Another area of great significance is the provision of a platform to the national as well as the international actors for getting the issues redressed. This has helped the world in providing them the platform for addressing international issues while imposing the international rules and norms for the resolution of these issues.

This role of the US at the level of global leadership has been referred to by some observers as of varying degrees by approving or disapproving of the role played by the United States in global affairs. Some such examples include the US being the leader of the liberal world, role of being undefeatable power, state with unlimited power, system setter for the rest of the world, hyperpower, role of being the world soldier-ship, or world hegemon (Rourke \& Moodie, 2020). The role of being a global leader has led to the excessive involvement of the US in international affairs, which has earned the US with various phases. The US has been termed as a nation pursuing a foreign policy of international nature connoting the foreign policy to engage the whole world or the policy of being interested in the profound rendezvous of the world. This policy aims at providing public goods, a foreign policy of liberalism based on the doctrine of international order, or the policy of liberal hegemony; which can better be described as an interfering foreign policy, or a foreign policy of the global nature looking for domination over the entire world making it a decisive factor in determining world politics.

\section{Defense and Promotion of Liberal International Order}

The second important element of the US role since the culmination of World War II which can be viewed concerning the first key element, is the defending and promotion of the liberal international order. This order has come into existence as a result of the support of the allied powers which they have shown to the United States (Dutta, 2020). Although, the liberal international order has been a common terminology yet many connotations are used to explain this order:

- Showing regard concerning the geographical integrity of the states and refusal to accept any change like the international boundaries either through peaceful or coercive means;

- Resolution of disputes through peaceful means on a priority basis, without the use of power or oppression and in a manner in consonance with the norms of the international law;

- Showing regard for international law, global norms and rules, and universal values including human rights;

- The use of liberal international trading and investment systems for the advancement of open rule-based economic engagement, development, growth, and prosperity.

The first element is the most important one in giving legal cover to the role of the United States since it believes in providing respect to territorial integrity to the states which provides the legal basis for the existing status quo of the states. This will help in preventing to accept any change in the international borders of a particular state whether by force or coercion. Another important characteristic of the liberal international order is to resolve all outstanding issues through peaceful means without taking recourse to any forceful measures. Even here in the resolution of disputes, the norms and rules, and values of the global and international law given primacy to settle the disputes more amicably. Global rules, norms, and international values play the most significant part in the affairs of the United States while dealing with any issue concerning the world. The system of liberal international trading and investment is used for the advancement of economic growth, economic development, and peace and prosperity of the world (Ikenberry, 2011).

Most of these key elements can be taken in collective form as forming what is referred to as rules-based international order. The rules-based order stands for upholding the cause of law and order in the world through well-established dogmas. This often leads to the establishment of a wellorganized system of coexistence. None of the above-mentioned parameters can be taken in isolation as they are interrelated and closely interwoven in many respects. The liberal international order, like other international orders, does have some inherent deficiencies;

- Incompleteness in terms of geographic reach;

- Having no fixity but is revolutionary that keeps on evolving;

- $\quad$ Aspects of being violated by its supporters;

- Resistance or rejection by certain state and non-state actors.

- Certain stresses and challenges faced by the US. 
It is also important that some observers are of the view that the new liberal international order is more of a myth than a reality (Patrick, 2019). Owing to its limitations concerning inaccessibility, it also creates problems for the countries of the world to have access to the international market while making the demand for the goods and supplies of the services. While on the other hand, the supporters of the new international order are of the view that despite limitations of the order, it cannot be termed as a myth though it presents a different picture from that of the international order that preceded it.

The liberal international order emerged in post-World War-II with its chief exponents as the United States and its allied powers. It was at that time that the United States was the only country having the potential and willingness for the creation of the new international order. So, the major element in the creation of this order was the US itself that alone had the capacity of establishing the order. The sole purpose of this order was the avoidance of the major deadly wars and widespread economic disruption during the first half of the $20^{\text {th }}$ century that brought about the two World Wars causing irreparable loss to the entire world (Service, 2020).

The liberal international order has been the product of the United States and its allies and has been dominating the entire world for the last seven decades. It has been instrumental in promoting economic openness, democratic values, and secured cooperation coupled with the creation of multilateral institutions (Dutta, 2020). This made the US to become a world leader and provided her the opportunity in stabilizing the economy and promoting the free world values, but it also helped in creating the system of response, ideas, and agenda based on the doctrine of liberty. It is admitted that the liberal international order is an open, and loosely rules-based with a progressive orientation system. The United Nations (UN), World Trade Organization (WTO), North Atlantic Treaty Organization NATO), and Group 20 (G20) took a central role in expanding the economy (Dutta, 2020). The main features of liberal international order are democracy, liberal market mechanism, and immigration. The logic behind it is to give up some part of sovereignty for peace and build economic prosperity through free trade.

The willingness of the US for the creation of the liberal international order has also been viewed as a matter of national self-interest to the United States by most of the scholars. This reflects the belief that this may aim at supporting the US security, political and economic objectives with its emphasis on its interest in some of the key areas of the world. The main criticism of the liberal international order is that it upholds the cause of the US while promoting the US hegemony over the rest of the world. They support the view that it has changed the concept of bipolarity to the concept of uni-polarity where the US has become a world soldier. It is correct that the post-disintegration of the former USSR has resulted in the creation of a unipolar world while before the disintegration, it was a bipolar world with two antagonistic ideologies.

\section{Defense and Promotion of Freedom, Democracy, and Human Rights}

The third important element of the US circles round defense and promotion of freedom, democracy, and human rights. These are termed as universal values by the United States while making criticism over the authoritarian and any illiberal government in the world. So, any authoritarian and despotic form of government is criticized while giving too much support for the liberal form of government. In this type of government, there is a greater ratio of cooperation and coordination among the various governments of the world (State, 2020). This element of the objective of the US is viewed as most in consonance with the core values of democracy in the United States but also in harmony with what may be termed as the democratic peace theory. This theory believes in upholding the cause of cooperation and coordination and is very much in harmony and consonance with the demands of the people and is very less likely to go to war against other states (Jegat, 2015).

Upholding the cause of defending and relying on the promotion of freedom, working for democratic values, and standing for the cause of human rights may be regarded as the central aspects of the US soft power because it works for the encouragement of governments based on the doctrine of like-mindedness as well as administrations and individuals working in other countries while showing their intention to work with the US. It has the capacity for shaping the behavior of authoritarian and illiberal governments that act against the interest of the United States. The main concern of this system is to encourage the democratic governments by giving them the opportunity of cooperation and interdependence in the field of economy and other related fields. It also discourages the authoritarian and dictatorial governments not to become part of the system by imposing sanctions upon them. 


\section{Prevention of Emergence of Regional Hegemons in Eurasia}

The fourth element of the traditional US role in the world since World War-II, which the US does not state explicitly in public and which is directed against the emergence of regional hegemons in Eurasia (Iseri, 2009). This objective reflects the US perspective on the grounds of geopolitical perspective and strategy developed by the US during the post-World War-II period, incorporating two key decrees.

- Keeping in view the size and strength of the people, the various resources and aspects concerning the economy in Eurasia, a regional hegemon in Eurasia is likely to represent a concentration of power large enough with the potential of threatening the US interests; and

- That Eurasia is not dependently self-regulating while dealing with other states for taking any preventive action against the regional hegemon or assist with any (CRS, 2020).

It is significant to mention that the huge size and population and concentration of power in the hands of Eurasia poses threat to the interests of the United States. This has placed the US on high alert for countering the hegemonic designs of Eurasia and is trying to establish its hegemony in the world. But the US may not need to focus so much on this factor as the Eurasia is not strong enough to counter powers like the United States all alone and may need the military strength and assistance of other regional powers outside the Eurasian domain to counterbalance the power and strength of the US. Anyhow, despite this fact the US does realize the growing strength of Eurasia and tries its best to do whatever it can do for countering the military and economic strength of it.

The desire to avoid the development of the hegemonic power of Eurasia can be seen by some scholars through the prism of dividing the power in the region of Eurasia. This may also be referred to as the prevention of key areas in Eurasia falling under the direct domain of a unified authority or the appearance of an influential sphere resulting in the formation of one or more hegemonic powers in the region of Eurasia. The changing role of the United States in the affairs of the world has been viewed through different angles by the various scholars and actors of the US within its circles (Coalson, 2017). They have their views and observations regarding the changing role played by the US in the politics of the world in the post-World War-II. This view has been held by the four schools of thought, expressing their views in their way.

\section{The First set of Observers}

It is also important to mention that there is a divergence of opinion between the various schools of thought that the US has adopted the policy of changing role during the Trump Administration. This view is held by some of the critics of the Trump administration. This view holds that there is a substantial change in the role of the US in the world while making alterations in some or all of the key four elements, mentioned above. These scholars vary in their approaches, but most of these observers put forward the argument that the American's administration priority is the guidepost for the US foreign policy while other actions by the administration and statements from a new US role characterized by some of the following key factors;

- Volunteer retreat from the global leader in some cases as is clear in some decisions of withdrawal, for example, the decision by the US administration to withdraw from some agreements, treaties, and pacts Service, 2020).

- Reliance on the policy of unilateralism in the affairs of the world, making it a superpower while having a dominant role in the settlement of disputes and outstanding issues of the world Service, 2020).

- Reduced willingness to have a role in the affairs of the world through various institutions, particularly the international and multilateral institutions, or entering into pacts, agreements, and treaties with the rest of the world to ensure its presence in almost all affairs of international nature. In this regard, the earlier suggestions for reducing State Department funding, and delaying tactics while making recruitments to the key appointments. But it also focuses on signing agreements with the countries when it thinks that the US engagement in that area may cause huge financial loss to its exchequer. An example of it is the withdrawal of the US forces from Afghanistan (Tariq, 2020).

- Acceptance towards US isolation or near-isolation on certain issues at the international and global level. This will lead to a policy of neutrality in certain cases where the US may not participate in the affairs of some of the countries. 


\section{The second set of observers}

These observers also view the affinity of the US president for certain authoritarian or illiberal leaders, and his stubbornness for criticizing Russia since improving relations with it may not be in the best interest of the US. This approach of authoritarian nature by the US president has received criticism from various quarters of the US administration since Russia has always been anti-US in most of the affairs of the world in the international politics.

While other observers, mainly supporters of the Trump administration, disagree with all or some of these observations. They do acknowledge the changing role of the Trump administration in foreign policy in certain areas as compared to the policies pursued by the Obama administration. They are of the view that has been very little change as compared to the previous policies but more continuity in the US role in the world. The following points are put forward by these observers for the substantiation of their view.

- Reaffirming of the statements by the administration showing US support for the NATO, as well as strategies by the US administration for strengthening and improving the military capabilities of the US in Europe to deter potential Russian aggression in Europe.

- The willingness by the Trump administration for imposing and maintaining a variety of sanctions against Russia.

- The Free and Open Indo Pacific Policy (FOIPP) of the US administration for giving guidance and direction to the US policy in the Indo Pacific Region.

- The confrontational policy of the US administration towards China, including the plan for increasing funding for the US foreign assistance programs against China for curtailing the influence of China in the continents of Africa, Asia, and the Americas.

\section{The third set of observers}

Still, some observers see a mixed or confusing situation of the above two different schools of thought. For them, it is difficult to discern whether the US role is changing during the Trump administration or there has been no change at all. They see incoherence in the foreign policies of the administration and the apparent views of the president on certain issues. These include the values of US alliances, the acceptability of certain actions by Russia or North Korea, and the significance of democratic values coupled with fundamental human rights as universal values, which have been contradicted by some of the senior administration officials through their statements or actions.

\section{The fourth set of observers}

The fourth set of observers is of the view that the change began earlier during the Obama administration and that too concerning the question of whether the US has made any attempt to withdraw from the world leader or not. The supporters of this view put forward the following views;

- $\quad$ The reduced role of the US in military presence and operations in some countries such as Iraq and Afghanistan, and focus instead on domestic policies for rebuilding of US initiatives.

- Restrained response to Russian actions in China and Eastern Ukraine and adapt to less Conclusion cooperative and more confrontational relationship with China and Russia.

The US has been instrumental in playing the most significant role in determining the outstanding issues among the various countries of the world in the post- World War-II era. But here, the international norms and rules have also been given regarding by sticking to the well-established rules and dogmas of the world. It is an un-denying fact that the US has been pursuing a policy of liberal internationalism that is more in consonance with making it a world power or world hegemon. Another area of great concern for the US is to defend and promote the liberal international order in the world to get the maximum benefit out of the policies of the United States in upholding the cause of its hegemony. This will make it more powerful and strong in the decision-making power of the world. In this connotation, the US has been strongly supported by its allied powers, which is another important development in making it strong since all the allied powers have helped provide timely assistance. The liberal international order is also criticized for the inaccessibility by some of the states as they have no easy access to the mechanism of the international market. Most of these states term it as a myth with no practical manifestation rather they term it as a fallacious mechanism. The greatest criticism on the liberal international order is that it stands for upholding the cause of the United States over the entire world and tries to make it a world soldier by vesting more and more power in it. It has led to the creation of the unipolar world and has done away with the doctrine of the bi-polar world. 
A school of thought refers to the changing role of the US as initiated by the Trump Administration but some scholars opine that the change began earlier in the previous administrations. This view is supported by the critics of the Trump administration emphasizing that during this period there has been a change in the US role either in partial form or in all the four key sectors of the US administration. This finds expression in some of the key areas such as withdrawal from the various treaties and pacts signed by it with the various countries of the world. As a result, the US has relied more on the policy of unilateralism rather than the policy of multilateralism or polarizing the world depending on two different blocks. The second school of thought views the role of the US current administration in the perspectives of the inclination towards authoritarianism and improvement in relations with Russia through the scholars and the US intelligence agencies look at the designs of Russia with suspicion. According to them, the Russian designs are directed against the US interest both at the regional and global level. Still, the third school of thought holds a different view and share a mixed or confusing view by indoctrinating that there has been no change in the role of the US in the affairs of the world. They hold that the change has been there as a consequence of the change in the foreign policy as per the needs and requirements of the world. The fourth school of thought shares the view that the change has already begun in the US role and that too during the regime of President Obama concerning whether the US has reduced its role or withdrawn from the global leadership.

It is crystal clear that the US has been playing the most significant role in the affairs of the entire world. Critics and scholars vary in their views in so far as its role is concerned. Whether the change began earlier during the presidency of the Obama administration or the presidency of the Trump administration or even earlier but the fact is evident that clear change has been visible in the attitude of the US in some countries which is very clear. A glaring example of it is the US-Taliban Talks and Withdrawal of the US from Afghanistan which is a clear indication that the US is moving from the policy of unilateralism towards the policy of multilateralism (Tariq, 2020).

\section{References}

Coalson, R. (2017, December 17). Searching for America's Changing Role in A Changing World. Gandhara. Retrieved from https://gandhara.rferl.org/a/united-states-role-in-a-changing-world/ 28948494.html

CRS. (August 21, 2020). Defense Primer: Geography, Strategy and US FOrce Design. Congressional Research Service IF10485, https://crsreport.congress.gov/IF10485.

Dutta, I. (2020, July 16). The Future of the Liberal International Order. Diplomatist Dialogue on India: A Global Power House. Retrieved from https://diplomatist.com/2020/07/16/the-futureof-the-liberal-international-order/

Ikenberry, G. J. (2011, May/June ). The Future of the Liberal World Order: Internationalism After America. Retrieved from https://www.foreignaffairs.com/articles/2011-05-01/future-liberalworld-order

Iseri, E. (2009). The US Grand Strategy and the Eurasian Heartland in the Twenty-First Century. Geopolitics. Retrieved from http://www.tandfonline.com/loi/fgeo20

Jegat, J. (2015, November 24). Democratic Peace Theory, Power, and Economic Interdependence. EInternational Relations. Retrieved from https://www.e-ir.info/2015/11/24/democratic-peacetheory-power-and-economic-interdependence/

Patrick, S. M. (2019, Jan 15). The Liberal World Order is Dying. What Comes Next ? World Politics Review. Retrieved from https://www.worldpoliticsreview.com/insights/27192/the-liberalworld-order-is-dying-what-comes-next

Scheffer, A. H., Kinane, R., Quencez, M., \& Wickett, X. (2016, May 1). The Future of US Global Leadership: Implications for Europe, Canada, and Transatlantic Cooperation. German Marshall Fund of the United States, 20. Retrieved from https://www.jstor.org/ stable/resrep18777?seq=1\#metadata_info_tab_contents

Rourke, O Ronald \& Moodie Michael (2020). U.S. Role in the World: Background and Issues for Congress. Congressional Research Service, https://crsreports.congress.gov R44891.

Destro A. Reobert State,(2020). Human Rights and Democracy. State Department of the United States. Retrieved from https://www.state.gov/policy-issues/human-rights-and-democracy/

Tariq, M. (2020). US Withdrawal from Afghanistan: Latest Development and Security Situation. Sir Syed Journal of Education and Social Sciences Review, 3(2), 290-297.

Tariq, M. (2020). US-Afghan Talks: Myths and Realities. Global Political Review, V(I), 104-111. 